\title{
The Impact of Transformational Changes on the Socio-Economic Conditions of the Rural Population. An Example of Poland
}

\author{
Iwona Bąk (D), Katarzyna Wawrzyniak and Maciej Oesterreich *(D) \\ Department of Applied Mathematics in Economics, Faculty of Economics, West Pomeranian University of Technology, \\ Szczecin, Janickiego Street 31, 71-270 Szczecin, Poland; iwona.bak@zut.edu.pl (I.B.); \\ katarzyna.wawrzyniak@zut.edu.pl (K.W.) \\ * Correspondence: maciej.oesterreich@zut.edu.pl
}

Citation: Bakk, I.; Wawrzyniak, K.; Oesterreich, M. The Impact of Transformational Changes on the Socio-Economic Conditions of the Rural Population. An Example of Poland. Agriculture 2021, 11, 403. https://doi.org/10.3390/agriculture 11050403

Academic Editor: Gioacchino Pappalardo

Received: 1 April 2021

Accepted: 28 April 2021

Published: 29 April 2021

Publisher's Note: MDPI stays neutral with regard to jurisdictional claims in published maps and institutional affiliations.

Copyright: (c) 2021 by the authors. Licensee MDPI, Basel, Switzerland. This article is an open access article distributed under the terms and conditions of the Creative Commons Attribution (CC BY) license (https:// creativecommons.org/licenses/by/ $4.0 /)$.
Abstract: The aim of the article is to show that in rural areas, with particular emphasis on former state-owned farms, which were created as a result of changes in the forms of land ownership, mainly in Central and Eastern European countries, the economic situation of households is still worse than in the areas where there were no State Agricultural Enterprises (PGR). Research in Poland served as a case study. Selected methods of descriptive statistics and multivariate comparative analysis were used in the analyses. The results presented in the study at different levels of aggregation (voivodeships, poviats, and communes) allowed the identification of the regularities in the situation of rural areas. Among the beneficiaries of social assistance, most of the people live in rural areas and have a high unemployment rate; the problem of unemployment especially concerns those areas where the rural population with lower education levels predominates. Moreover, in former state-owned farms, the total disposable income per person is lower than in other areas, and the funds from the government program "Rodzina 500+" constitute a significant contribution to household budgets.

Keywords: transformational changes; rural population; social assistance; regression trees

\section{Introduction}

The collapse of the communist system in Central and Eastern Europe at the turn of the 1980s and 1990s resulted in system transformation on the political, economic, and social levels. Reforms began that included restoring land tenure to precollectivization owners or their heirs. The process of decollectivization, similarly to collectivization before, had a different pace and scope in individual countries of the former socialist bloc [1]. In the following years, market forces and various institutions' operations were the main structural change drivers. The latter played a vital role in the pre-accession period and after individual countries acceded to the European Union.

As Halamska [2] points out, in the long term, in Polish rural areas, similarly to Western and Central Europe, four significant processes are changing its face: deagrarianization (the process relating to the whole of society, which is the progressive reduction in the share of rural population in the national population); deagrarisation (the process of reducing agrarianism, i.e., the impact of agriculture on the economy and society); the shaping of a new model of agriculture (peasantization/depeasantization); and restratification. The most important effects of these processes include: (1) the new place of rural areas in society, (2) the new place of agriculture in society and the economy, and (3) the new structure of rural areas as a social subsystem.

The collapse of State Agricultural Enterprises caused a whole range of problems in regions where they were the only employers. This often led to a drastic reduction in jobs and mass layoffs, which resulted in increasing unemployment among the inhabitants of post-state farm villages. Unemployment was accompanied by enormous impoverishment of the community, and the intensity of pathological phenomena was increasing. Social 
passivity and helplessness have become a general feature of the post-state farm communities. Although the state-owned farms have been gone for almost 30 years, it does not mean that they have disappeared without a trace. Apart from the devastated property, including residential buildings and production means, there were also people-former employees of state-owned farms with their families. Some of them have managed to find a place in the free market reality, but most of them have not, passing on this helplessness to the next generations.

These observations were the reason for the authors to initiate research to demonstrate that households' economic situation in former state-owned farm areas is still worse than in areas where there were no state farms. Research in rural areas in Poland served as a case study. Selected methods of descriptive statistics and multivariate comparative analysis were used in the analyzes.

The added value of the paper is the presentation of research results at individual levels of data aggregation (communes, poviats, and voivodeships). This type of approach was used in this study for the first time. As a rule, this type of research is limited to large territorial units.

The layout of this article includes an introduction that presents the primary purpose of the paper and explains the authors' most essential motivations to research the impact of transformational changes on the socioeconomic conditions of the rural population. In the following part of the work-devoted to the situation in Poland-statistical data used in the study are presented, and the research procedure used in the study is described. The article ends with the presentation of research results, discussion, and conclusions resulting from the research.

\section{Materials and Methods}

\subsection{Literature Review}

The socioeconomic situation in rural areas is of interest to scientists from around the world [3-13]. The rural environment is constantly transforming, as a result of which it becomes part of the global, national economy, integrally connected with the rest of society. In general, however, rural areas are much less developed than urban areas in social, cultural, and economic terms $[11,14,15]$. According to Khan [4], the causes of poverty are complex and multidimensional, and the differences in poverty concern gender, ethnicity, age, location (rural and urban), and the source of income and public order. The population in rural areas is quite diverse in terms of the prevalence and extent of poverty, both in terms of the problems they face and possible solutions to them. Despite the blurring of differences and equalizing the quality of life in the city and the countryside, one can still identify marginalized and degraded areas or areas threatened with degradation. As indicated by the International Labor Organization (ILO), $88 \%$ of the extremely poor population lives in rural areas. In the case of people working in rural areas, this percentage is $20 \%$ compared to $4 \%$ of people working in cities [16]. In turn, in developing countries, over $65 \%$ of people working in agriculture live below the poverty line [17]. Marginalization often affects smaller municipalities (villages and small towns), often treated as rural areas. The natural cause of marginalization is usually the spatial distance (considerable distance from the main development centers and communication routes). Distance is undoubtedly a barrier, although, in the light of the research carried out, it turns out that it is not the only and not the greatest one.

At this point, it is worth considering the answer to the question why the socioeconomic situation of the population in rural areas differs from the situation in urban areas? The answer to this question can be sought by identifying the reasons for this state of affairs. These reasons, the main determinants of the problems affecting the population living in rural areas in the European Union (as well as in other countries), including Poland, can be grouped into five areas [18-20]:

1. Demographics: the outflow of people from the countryside, mostly to cities, and economic emigration, aging of the population, and progressing masculinization [21]; 
2. Distance, infrastructure, and access to basic services: limited access to public and private services, more unsatisfactory living conditions compared to cities, demanding access to transport and related transport problems, inferior conditions of road infrastructure, and problems with access to ICT services and their worse quality [20,22,23];

3. Education and human capital: a high percentage of people with a lower level of education, lower quality of education (at all levels), difficult access to educational services, and social exclusion [24,25];

4. Specific problems of the labor market in rural areas: the agricultural sector is characterized by a seasonal type of production that makes it impossible to find a permanent job in the area, high fragmentation of farms, and their low development potential [26-28];

5. "Vicious circles": an area related to the four areas mentioned above and their overlapping, thus increasing the problems of the rural population and their further transmission [29].

In reality, there are many more reasons for degradation and marginalization, and these barriers are often more challenging to overcome than physical distance. In the case of many rural areas, the historically conditioned form of land ownership is essential. This applies especially to Central and Eastern European countries, which found themselves in the camp of socialist countries after World War II. In the socialist system, private land ownership had to be replaced by state property to enable equal wealth distribution. This meant establishing the State Agricultural Enterprise (PGR) - large production units that used common labor resources and then equally divided the obtained products and revenues [30]. Despite the same vision of the agricultural economy in these countries, the process of collectivization was different [31]. For example, in Hungary, all estates were expropriated and reduced to a maximum of 57 hectares, and in 1966 as much as $86 \%$ of the land was owned by agricultural cooperatives and state-owned agricultural enterprises. In Bulgaria, the process was slower: in 1950, the newly formed collectives controlled only $51 \%$ of the arable land, and the peasants, who belonged to the cooperatives, still held the ownership of land. It was only in 1988 that approximately $90 \%$ of the land belonged to the socialized sector, and the few individual farms operated mainly in mountainous areas and other areas less suitable for agricultural production. In Romania, collectivization was completed in 1962 when 77\% of agricultural land came under state control. In Poland, in the late 1940s, the government approved large landowners' expropriation but did not achieve this goal. In 1956, however, the creation of large agricultural enterprises was abandoned, and part of the cooperative land was given to small private owners.

\subsection{Research Material}

The implementation of the research goal formulated in the paper began with identifying the spatial diversity of former state-owned farm areas in Poland. For this purpose, the information provided by the National Agricultural Support Center (KOWR) on the areas where the resources of State Agricultural Enterprises (PGR) were located in the Agricultural Property Stock of the Treasury (WRSP), including PGR housing estates, were used. These data included a list of former state-owned farm areas, taking into account the number of flats sold in individual registration (geodetic) precincts as of 26 June 2020. For each precinct, information about its location was provided according to the systematics: voivodeship, poviat, and commune. It follows that at each level of data aggregation, it was possible to calculate the indicator defined as the number of flats sold from the state-owned farm resources per 10,000 total population $\left(W_{1}\right)$. This indicator made it possible to visualize the intensity of the phenomenon under study in spatial terms, and at the same time, allowed us to identify those areas where there may still be problems related to the collapse of state-owned farms. In further studies, this indicator was considered a dependent variable, the higher values of which indicate that in these areas the effects of the liquidation of state-owned farms concern a more significant number of people. To verify the hypothesis that the socioeconomic situation of households in former state-owned farms is worse than in the areas where there were no state-owned farms, a set of indicators was proposed that 
characterize this situation at different levels of aggregation (voivodeships, poviats, and communes). Due to the limited number of data at the lowest aggregation levels (poviats and communes), the following set of indicators was established in order to ensure the comparability of the obtained conclusions:

- the number of beneficiaries of community social assistance per 10,000 people $\left(W_{2}\right)$;

- the coverage of using community social assistance in total, i.e., the share of the number of beneficiaries in the total population in \% $\left(W_{3}\right)$;

- the range of using community social assistance below the income criterion, i.e., the share of the number of beneficiaries with income below the income criterion in the total population in $\%\left(W_{4}\right)$;

- the range of using community social assistance above the income criterion, i.e., the share of the number of beneficiaries with income above the income criterion in the total population in $\%\left(W_{5}\right)$;

- $\quad$ the share of the unemployed in the working-age population in \% $\left(W_{6}\right)$;

- total income per capita in PLN $\left(W_{7}\right)$;

- $\quad$ own income per capita in PLN $\left(W_{8}\right)$;

- the number of crimes identified by the police in total per 1000 inhabitants $\left(W_{9}\right)$ at the level of voivodeships and poviats;

- and gross enrollment rate $\left(W_{10}\right)$ : primary schools at the level of poviats and communes. At the level of voivodeships, this indicator was replaced by the share of the population with higher education in the number of the economically active and inactive population $\left(W_{11}\right)$ and the share of the population with at most a lower secondary education in the number of the economically active and inactive population $\left(W_{12}\right)$.

Indicators $W_{2}-W_{5}$ characterize the financial situation of households in the study area, indicator $W_{6}$ characterizes the situation on the labor market, indicators $W_{7}-W_{8}$ characterize the financial situation of a given area, indicator $\left(W_{9}\right)$ characterizes the crime rate in a given area, and indicators $\left(W_{10}-W_{12}\right)$ characterize the level of education of the population.

Additionally, at each level of aggregation, another indicator $\left(W_{13}\right)$ was introduced related to the place of residence of the population (city or village). In the case of voivodeships and poviats, this indicator was defined as the share of the rural population in the total population in \%, while for communes as a type of communes (urban, urban-rural, and rural). The purpose of introducing this indicator was to show the degree of differentiation in the standard of living in urban and rural areas.

Statistical data on indicators $W_{2}-W_{13}$ at various aggregation levels were taken from the Local Data Bank of the Central Statistical Office (GUS) in Poland.

Various methods were used to achieve the aim of the work, and thus to verify the formulated hypothesis. Various methods were applied, the use of which was related to the size of the surveyed communities. In the case of voivodeships $(n=16)$, it was decided to use Pearson's correlation coefficients. For poviats $(n=380)$ and communes $(n=2411)$, regression trees were used first, thanks to which-based on the values of independent variables (indicators characterizing the socioeconomic situation) - the groups of poviats and communes differing in the values of the dependent variable were distinguished (the number of flats sold from the PPGR resources per 10,000 people in total). Then, within the framework of the selected groups, a detailed statistical analysis of the distribution of the values of indicators used in the study was performed.

\subsection{Research Method}

Regression trees are classified as classification trees and are used when the dependent variable is quantitative. They are a graphic representation of the model in the form of [32-35]:

$$
Y=f\left(\mathbf{x}_{i}\right)=\sum_{k=1}^{K} \alpha_{k} \mathbf{I}\left(\mathbf{x}_{i} \in R_{k}\right)
$$


where:

$Y$-a quantitative dependent variable, $\mathbf{x}_{i}=\left[x_{i 1}, x_{i 2}, \ldots, x_{i L}\right]$ 一observations from a recognizable set, $\alpha_{k}$-model parameters determined for a quantitative dependent variable according to the formula:

$$
\alpha_{k}=\frac{1}{N(k)} \sum_{\mathbf{x}_{i} \in R_{k}} y_{i}
$$

where:

$y_{i}$-values of the dependent variable in the segment $R_{k}, N(k)$-number of observations in the segment $R_{k}, I$-indicator function defined as:

$$
I(q)= \begin{cases}1 & \text { when } q \text { is true } \\ 0 & \text { when } q \text { is false }\end{cases}
$$

$R_{k}(k=1, \ldots, K ; K-$ number of segments)—subspace (segment) of the space of independent variables $\mathbf{X}^{L}\left(X_{1}, X_{2}, \ldots, X_{L} ; L-\right.$ number of independent variables), the way of defining it depends on the nature of independent variables, and so:

- $\quad$ for quantitative independent variables, each of the segments $R_{k}$ is defined by its boundaries in the space $\mathbf{X}^{L}$ as follows:

$$
\boldsymbol{I}\left(\mathbf{x}_{i} \in R_{k}\right)=\prod_{l=1}^{L} \boldsymbol{I}\left(v_{k l}^{(d)} \leq x_{i l} \leq v_{k l}^{(g)}\right)
$$

where the values $v_{k l}^{(d)}$ and $v_{k l}^{(g)}$ mean, respectively, the upper and lower limit of the segment in $l$-th dimension of space.

- For categorical independent variables each of the segments $R \_k$ is defined as:

$$
\boldsymbol{I}\left(\mathbf{x}_{i} \in R_{k}\right)=\prod_{l=1}^{L} \mathbf{I}\left(x_{i l} \in B_{k l}\right)
$$

where $B_{k l}$ is a subset of the independent variable category set $X_{L}$.

At this point, it is worth emphasizing that model 1 is created by assembling models (so-called local models) built in each of the $K$ segments into which the space of independent variables $\mathbf{X}^{L}$ is divided. The division of this space occurs recursively, i.e., at each step, the original fragment of the space is optimally divided into two or more parts using one of the independent variables. The independent variable which is the basis for the division of the space $\mathbf{X}^{L}$ and the location of the division of this space are selected so that the segments $R_{k}$ obtained in a given step are as homogeneous as possible concerning the values of the dependent variable $Y$ [36] (pp. 104-107). Since the standard deviation is most often used to test the degree of homogeneity of the value of a variable in a community, therefore, in the case of regression trees, the measure used to assess the quality of the division of the space of independent variables $\mathbf{X}^{L}$ is the variance of the dependent variable. A detailed discussion on this subject can be found in the works, e.g., [33].

Agresti [37] (p. 572) and Harell [38] (p. 31) drew attention to the recursive division of independent variable spaces when building a regression tree. According to them, there are five stages in the process of constructing regression trees:

1. Finding a predictor (independent variable) that allows the best possible binary split with its use, with the value of the selected statistical criterion greater than any other split using any other predictor;

2. Within each previously created subset, find the best predictor and the best partition that maximizes the selected criterion in the subset of observations obtained in the previous partition; 
3. Repeating the second step until less than $n$ observations remain to be split, where $n$ is typically from 20 to 100;

4. Compute the value of the dependent variable for each end node using summary statistics, e.g., mean, variance, or share (percentage);

5. Pruning the tree (choosing the number of end nodes) so that the tree constructed based on $90 \%$ of data observations from the input set is the best fit for the remaining $10 \%$.

The CART (C\&RT) procedure programmed in the package Statistica version 13.0 was used to determine the regression trees included in the article (see [39]). However, for the interpretation of end nodes (each tree has the so-called split nodes and end nodes-leaves), i.e., to the description of separated groups due to the level of selected independent variables and the level of the dependent variable, a set of logical division conditions was used, such as if ... then ..., which allowed for unequivocal classification of poviats and communes into separate groups.

\section{Results}

\subsection{Results for Voivodeships}

Figure 1 shows the differentiation in the number of flats sold from the state-owned farm resources per 10,000 population $\left(W_{1}\right)$ by voivodeship. The chart shows that in seven voivodeships, the level of the $W_{1}$ indicator significantly exceeds the level of this indicator for Poland $\left(W_{1}=77.2\right)$, with the most significant number of post-state farm areas being located in the following voivodeships: Zachodniopomorskie, Warmińsko-Mazurskie, and Lubuskie.

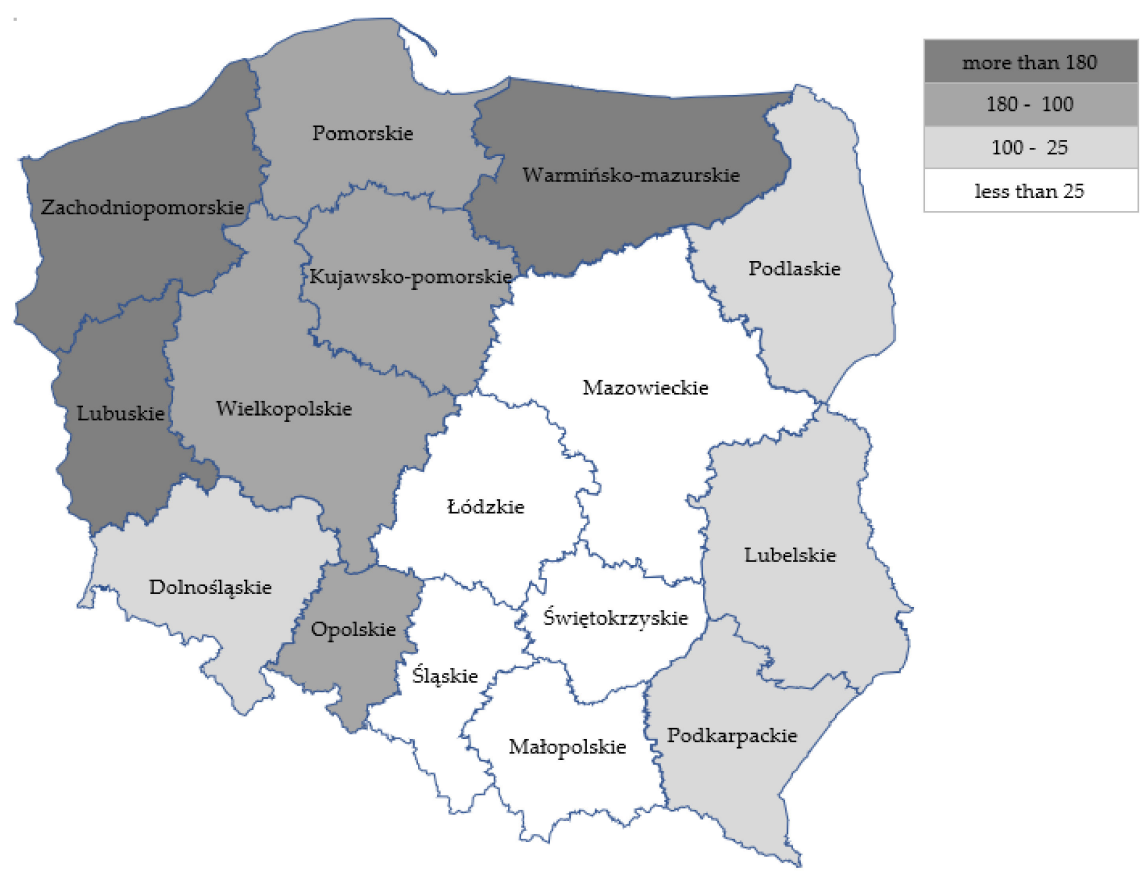

Figure 1. Number of flats sold from state-owned farm resources per 10,000 total population $\left(W_{1}\right)$ in voivodeships. Source: The authors' calculations based on data of: KOWR and GUS.

The spatial differentiation of voivodeships visible in Figure 1 in terms of the level of the $W_{1}$ indicator is the result of historical conditions. During the period of establishment of state-owned farms in Poland, they were located mainly in the western territories and in the north of the country (the so-called "regained lands"), because in these areas there was a lot of land without owners and they could be collectivized quite quickly. Over the following years (until 1989), these areas were characterized by a high share (exceeding $40 \%$ ) in the use of arable areas by socialized farms, including state-owned farms [40].

Pearson's correlation coefficients calculated between the individual indexes at this aggregation level are presented in Table 1. 
Table 1. Pearson's correlation coefficients between indices for voivodeships.

\begin{tabular}{ccccccccccccc}
\hline Indicators & $\boldsymbol{W}_{1}$ & $\boldsymbol{W}_{2}$ & $\boldsymbol{W}_{3}$ & $\boldsymbol{W}_{4}$ & $\boldsymbol{W}_{5}$ & $\boldsymbol{W}_{6}$ & $\boldsymbol{W}_{7}$ & $\boldsymbol{W}_{8}$ & $\boldsymbol{W}_{9}$ & $\boldsymbol{W}_{11}$ & $\boldsymbol{W}_{12}$ & $\boldsymbol{W}_{13}$ \\
\hline$W_{1}$ & 1.000 & 0.328 & 0.333 & 0.404 & 0.137 & -0.020 & -0.204 & -0.073 & 0.374 & -0.493 & 0.465 & -0.240 \\
$W_{2}$ & 0.328 & 1.000 & 1.000 & 0.971 & 0.896 & 0.775 & -0.350 & -0.633 & -0.525 & -0.524 & 0.864 & 0.427 \\
$W_{3}$ & 0.333 & 1.000 & 1.000 & 0.971 & 0.895 & 0.779 & -0.344 & -0.629 & -0.529 & -0.519 & 0.865 & 0.429 \\
$W_{4}$ & 0.404 & 0.971 & 0.971 & 1.000 & 0.764 & 0.734 & -0.307 & -0.547 & -0.406 & -0.504 & 0.912 & 0.259 \\
$W_{5}$ & 0.137 & 0.896 & 0.895 & 0.764 & 1.000 & 0.735 & -0.375 & -0.693 & -0.643 & -0.467 & 0.645 & 0.690 \\
$W_{6}$ & -0.020 & 0.775 & 0.779 & 0.734 & 0.735 & 1.000 & -0.322 & -0.584 & -0.566 & -0.244 & 0.705 & 0.543 \\
$W_{7}$ & -0.204 & -0.350 & -0.344 & -0.307 & -0.375 & -0.322 & 1.000 & 0.873 & 0.248 & 0.847 & -0.486 & -0.435 \\
$W_{8}$ & -0.073 & -0.633 & -0.629 & -0.547 & -0.693 & -0.584 & 0.873 & 1.000 & 0.552 & 0.729 & -0.630 & -0.676 \\
$W_{9}$ & 0.374 & -0.525 & -0.529 & -0.406 & -0.643 & -0.566 & 0.248 & 0.552 & 1.000 & 0.176 & -0.319 & -0.677 \\
$W_{11}$ & -0.493 & -0.524 & -0.519 & -0.504 & -0.467 & -0.244 & 0.847 & 0.729 & 0.176 & 1.000 & -0.573 & -0.190 \\
$W_{12}$ & 0.465 & 0.864 & 0.865 & 0.912 & 0.645 & 0.705 & -0.486 & -0.630 & -0.319 & -0.573 & 1.000 & 0.293 \\
$W_{13}$ & -0.240 & 0.427 & 0.429 & 0.259 & 0.690 & 0.543 & -0.435 & -0.676 & -0.677 & -0.190 & 0.293 & 1.000 \\
\hline
\end{tabular}

Source: The authors' calculations based on data of: KOWR and GUS.

The interpretation of the results from Table 1 began with analyzing the correlation coefficients from column 2. On their basis, it can be concluded that there is a clear positive correlation between the index $W_{1}$ and the indexes $W_{2}-W_{4}$, i.e., along with the increase in the number of flats sold, the number of people benefiting from community social assistance increases. This confirms the hypothesis formulated in the paper that households' financial situation in the former state-owned farms is worse (more people use social assistance) than in other areas. The above hypothesis is also positively verified by the additionally calculated coefficients of correlation between $W_{1}$ and the average monthly disposable income per 1 person from the "Rodzina 500+" childcare benefit and the average monthly disposable income per person in total, which amounted to 0.428 and -0.131 , respectively. The values of these ratios mean that the total disposable income per person in the former state-owned areas is lower than in other areas, and the funds from the government program "Rodzina 500+" constitute a significant contribution to household budgets. Calculation of the correlation coefficients for such a set of indicators is possible only at the level of voivodeships, because only at this level of aggregation, statistical data are available.

In column 2 above 0.3 , there are also values of the correlation coefficients between the index $W_{1}$ and the indicators: $W_{9}, W_{11}$, and $W_{12}$. These values allow verifying the following hypotheses positively that there is a greater crime in former state-owned farm areas and that the education of the population is lower (there are fewer people with higher education and more people with at most lower secondary education) than in areas where there were no state-owned farms.

The remaining correlation coefficients in column 2 are at a low or very low level, i.e., it is not possible to positively verify the hypotheses on their basis-at this level of aggregation-that the situation on the labor market in the former state-owned farm areas is worse and that the income of voivodeships per capita is lower than in other areas.

When analyzing the correlation coefficients from Table 1 , it is worth paying attention to the values of the coefficients between the indicator $W_{6}$ and the other indicators (column 7 in Table 1). On their basis, it is possible to confirm the commonly known regularities that in areas with high unemployment, the number of beneficiaries of community social assistance is more significant, that own and total incomes are lower, and that higher unemployment is observed in those areas with a predominant number of rural population with lower education.

\subsection{Results for Poviats}

The choropleth map in Figure 2 shows that former state-owned farm areas are located mainly in poviats located in the north and west of Poland, i.e., in the following voivodeships: Zachodniopomorskie, Lubuskie, and Warmińsko-Mazurskie. The biggest number of flats per 10,000 of the total population $\left(W_{1}=1032.5\right)$ was observed in the Łobeski poviat (Zachodniopomorskie voivodeship). In 40 poviats, no flat was sold from the state-owned farm resources, of which 28 poviats were cities with poviat status. 


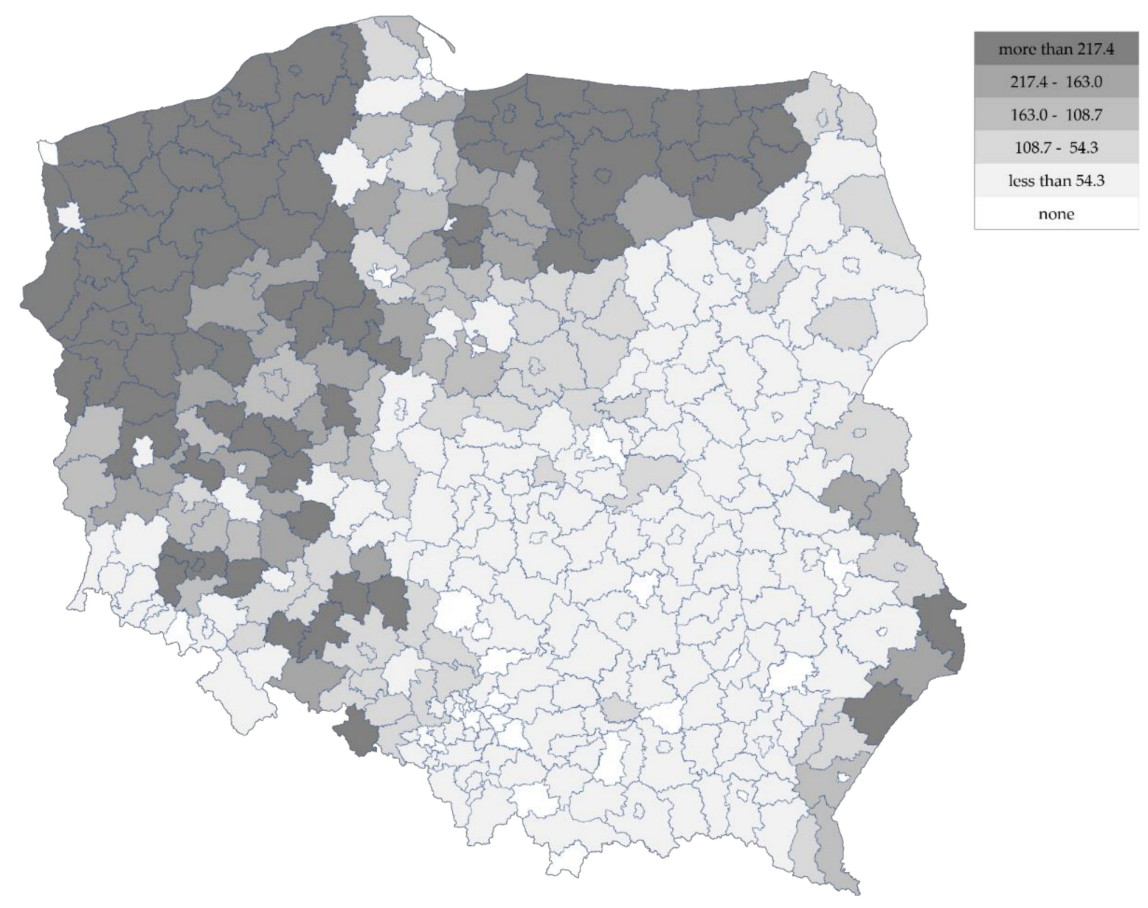

Figure 2. Number of flats sold from state-owned farm resources per 10,000 total population $\left(W_{1}\right)$ in poviats. Source: The authors' calculations based on data of: KOWR and GUS.

At this aggregation level, the starting point for detailed statistical analysis was the regression tree, in which the dependent variable was the index $W_{1}$, and the independent variables were the indexes $W_{2}-W_{10}$ and $W_{13}$. As a result of the applied C\&T procedure, a sequence of 18 trees was obtained for poviats $(n=380)$, of which tree no. 14 was selected (Figure 3 ), for which two conditions were simultaneously met: the maximum complexity of the tree and the relatively lowest cost of the cross-validation (see [36] (pp. 115-117); [41] (p. 242)). The tree selected for analysis has five divided nodes and six end nodes, and it is the end nodes that contain information that allows for characterizing the separated groups, but only because of the average level and the variance of the dependent variable and the selected values used in the construction of the independent variable tree.

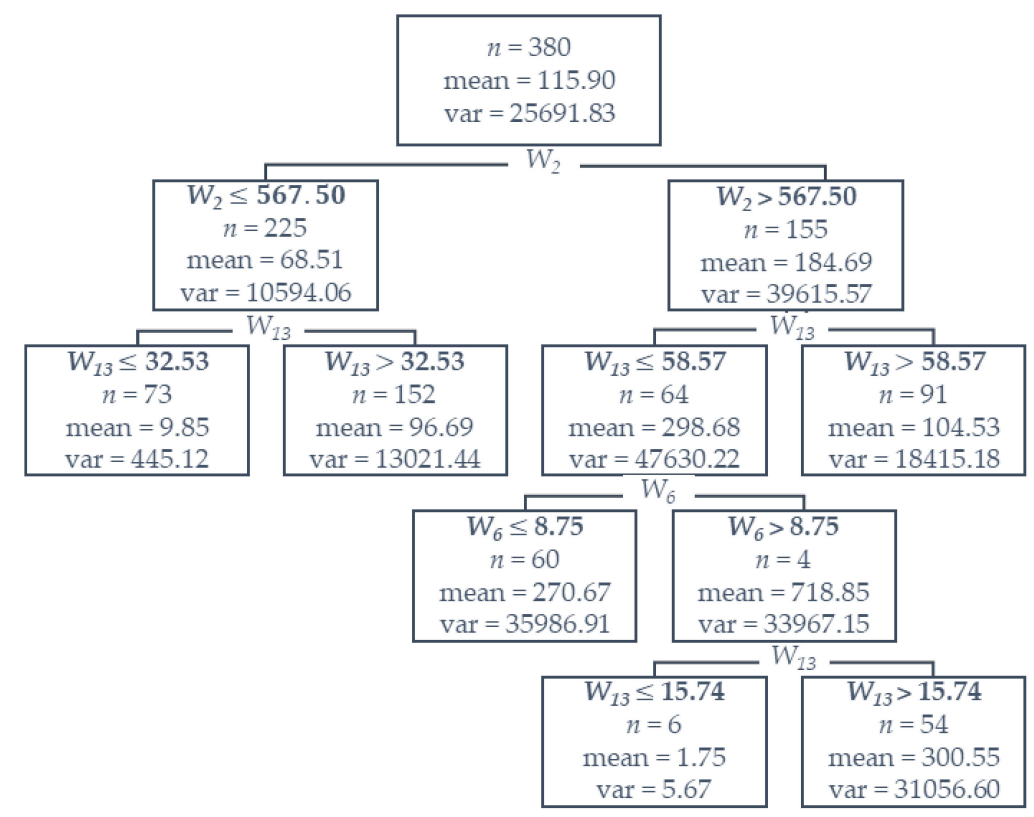

Figure 3. Regression tree for the indicator $W_{1}$ at the poviat level. Source: The authors' calculations in Statistica 13, based on data of: KOWR and GUS. 
The above tree shows that out of ten indices (independent variables), only three: $W_{2}$ (the number of beneficiaries of community social assistance per 10,000 population), $W_{6}$ (the share of the unemployed in the working-age population), and $W_{13}$ (the share of the rural population in the total population) allowed us to distinguish six groups of poviats (terminal nodes), which significantly differed from one another in the average level and the degree of differentiation of the value of the indicator $W_{1}$ (the number of flats sold per 10,000 population). The selected groups of poviats were characterized in the following way using a set of logical division conditions, such as if ..., then ... :

- group I $(n=73)$-if the number of beneficiaries per 10,000 population does not exceed 567.5 and if the share of the rural population in the total population does not exceed $35.53 \%$, the average value of the $W_{1}$ indicator is 9.85 , and the variance is 445.12 ;

- group II $(n=152)$ - if the number of beneficiaries per 10,000 population does not exceed 567.5 and if the share of the rural population in the total population is greater than $35.53 \%$, the average value of the $W_{1}$ indicator is 96.69 , and the variance is $13,021.44$;

- group III ( $n=91)$-if the number of beneficiaries per 10,000 population is above 567.5 and if the share of the rural population in the total population is greater than $58.57 \%$, the average value of the $W_{1}$ indicator is 104.53, and the variance is 18,415.18;

- group IV $(n=4)$-if the number of beneficiaries per 10,000 population is above 567.5 and if the share of the rural population in the total population does not exceed $58.57 \%$, but the share of the unemployed in the working-age population is greater than $8.75 \%$, the average value of the indicator $W_{1}$ is 718.85 , and the variance is $33,967.15$;

- group V $(n=6)$-if the number of beneficiaries per 10,000 population is over 567.5 and if the share of the rural population in the total population does not exceed $15.74 \%$ and the share of the unemployed in the working-age population is not greater than $8.75 \%$, the average value of the $W_{1}$ indicator is 1.75 , and the variance 5.67;

- group VI $(n=54)$-if the number of beneficiaries per 10,000 population is above 567.5 and if the share of the rural population in the total population is in the range $(15.74 \%$; $58.57 \%>$ and the share of the unemployed in the working-age population is lower than $8.75 \%$, then the average value of the indicator $W_{1}$ is 300.55 , and the variance was $31,056.60$.

Now let us look at the above interpretations from the side of the $W_{1}$ indicator, the higher values of which prove that in these areas, the effects of the liquidation of stateowned farms concern a more significant number of people. We can then observe the following regularities:

- $\quad$ with low average values of the indicator $W_{1}$, i.e., with a smaller number of people exposed to the effects of liquidation of state-owned farms, the number of beneficiaries of community social assistance is lower and fewer people live in rural areas;

- $\quad$ and with higher mean values of the $W_{1}$ indicator, i.e., with a greater number of people exposed to the effects of the liquidation of state farms, the number of community social assistance beneficiaries increases, the number of people living in rural areas increases, and the share of the unemployed in the working-age population increases.

The observed regularities positively verify the hypothesis that both the financial situation of the population and their situation on the labor market are worse in the former state-owned areas than in other areas. If we assume that these two aspects (finance and work) significantly affect the population's standard of living, the research shows that this level is higher in urban areas than in rural areas.

As the selected regression tree enables the description of individual groups of poviats only based on the mean and variance of the dependent variable and one specific value used in the construction of the tree of independent variables, it was decided to analyze the distribution of the selected indexes in the selected groups in detail. Indicators $W_{3}-W_{5}$ were excluded from analysis due the fact that they characterize the same phenomenon (use of community social assistance) only in a different approach. The values of descriptive param- 
eters characterizing the average level, differentiation, and asymmetry of the distribution of indicators in individual groups of poviats are presented in Table 2.

Table 2. Parameters of the distribution of the values of indicators in groups of poviats ordered in ascending order according to the average values of the indicator $W_{1}$.

\begin{tabular}{cccccccccc}
\hline Groups & Parameters & $\boldsymbol{W}_{\mathbf{1}}$ & $\boldsymbol{W}_{\mathbf{2}}$ & $\boldsymbol{W}_{\mathbf{6}}$ & $\boldsymbol{W}_{\mathbf{7}}$ & $\boldsymbol{W}_{\mathbf{8}}$ & $\boldsymbol{W}_{\mathbf{9}}$ & $\boldsymbol{W}_{\mathbf{1 0}}$ & $\boldsymbol{W}_{\mathbf{1 3}}$ \\
\hline \multirow{2}{*}{$\mathrm{V}$} & mean & 1.75 & 676.00 & 5.54 & 6896.98 & 3250.92 & 22.82 & 105.00 & 0.00 \\
$n=6$ & Vs [\%] & 136.35 & 12.46 & 33.56 & 5.13 & 10.60 & 12.23 & 5.86 & - \\
& asymmetry & 1.47 & 0.48 & -0.77 & 0.58 & -1.87 & -0.77 & 0.01 & - \\
\hline \multirow{2}{*}{ I } & mean & 9.85 & 339.78 & 3.17 & 6639.80 & 3477.47 & 27.06 & 99.49 & 4.42 \\
$n=73$ & Vs [\%] & 214.26 & 30.13 & 48.64 & 18.01 & 28.91 & 36.52 & 6.02 & 230.08 \\
& asymmetry & 3.64 & 0.13 & 1.48 & 0.77 & 2.04 & 2.19 & 0.30 & 1.99 \\
\hline \multirow{2}{*}{ II } & mean & 96.69 & 419.47 & 3.45 & 5239.60 & 2370.24 & 18.10 & 93.88 & 54.89 \\
$n=152$ & Vs [\%] & 118.02 & 24.24 & 43.77 & 10.56 & 26.83 & 36.07 & 4.50 & 41.01 \\
& asymmetry & 1.55 & -0.52 & 1.46 & 1.93 & 1.73 & 1.73 & -0.93 & -0.72 \\
\hline \multirow{2}{*}{ III } & mean & 104.53 & 780.60 & 6.12 & 5175.22 & 1823.55 & 14.06 & 90.21 & 66.46 \\
$n=91$ & Vs [\%] & 129.82 & 22.43 & 38.63 & 7.80 & 22.99 & 30.97 & 5.12 & 34.14 \\
& asymmetry & 2.19 & 1.81 & 0.78 & 0.46 & 0.95 & 1.09 & -1.07 & -2.02 \\
\hline \multirow{2}{*}{ VI } & mean & 300.55 & 750.74 & 5.38 & 5109.90 & 2171.05 & 18.33 & 90.83 & 47.08 \\
$n=54$ & Vs [\%] & 58.64 & 18.25 & 29.91 & 6.52 & 16.09 & 26.71 & 2.72 & 21.61 \\
& asymmetry & 0.19 & 0.59 & 0.01 & 1.07 & 1.14 & 1.60 & 0.51 & -1.95 \\
\hline \multirow{2}{*}{ IV } & mean & 718.85 & 999.25 & 9.34 & 5003.88 & 1910.72 & 17.64 & 88.46 & 45.26 \\
$n=4$ & Vs [\%] & 25.64 & 15.52 & 3.92 & 2.99 & 9.33 & 12.53 & 0.49 & 3.96 \\
& asymmetry & 1.79 & -1.06 & 0.24 & 0.48 & 1.73 & -0.22 & -0.63 & -0.83 \\
\hline
\end{tabular}

Source: The authors' calculations based on data of: KOWR and GUS.

Based on the mean values presented in Table 2, it can be seen that with the increase of the mean values of the indicator $W_{1}$

- the number of people using community social assistance is increasing (the exception is group $\mathrm{V}$, in which there are quite a lot of social assistance beneficiaries),

- total incomes per capita decrease,

- $\quad$ and the gross enrollment rate is decreasing.

In the case of other indicators, such unambiguous regularities cannot be observed, although in most groups, the higher the values of the $W_{1}$ indicator, the higher the unemployment, the more people live in rural areas, and the crime rate decreases.

Analyzing the values of the coefficient of variation $\left(V_{S}\right)$, it can be concluded that the most diverse in the groups of poviats-except for group IV consisting of only 4 poviatsare the values of indicators: $W_{1}, W_{6}$ and $W_{13}$ (in most groups $V_{s}>30 \%$ ), while the smallest differentiation $\left(V_{s}<6.5 \%\right)$ was observed for the indicator $W_{10}$. In the case of other indicators, the differentiation ranges from 3 to $37 \%$, depending on the group of poviats.

For most groups, the distribution of indicators is characterized by a solid right-hand asymmetry (the asymmetry measure above 1 ), which means that in these groups, poviats with indicator values below the average prevail. Left-hand asymmetry occurs only in a few cases and concerns mainly the distribution of the $W_{13}$ indicator, which means that in these groups, prevail poviats with the above-average share of the rural population.

\subsection{Results for Communes}

The spatial differentiation of former state-owned farm areas at the municipal level is illustrated by the choropleth map for the value of the indicator $W_{1}$ (Figure 4). 


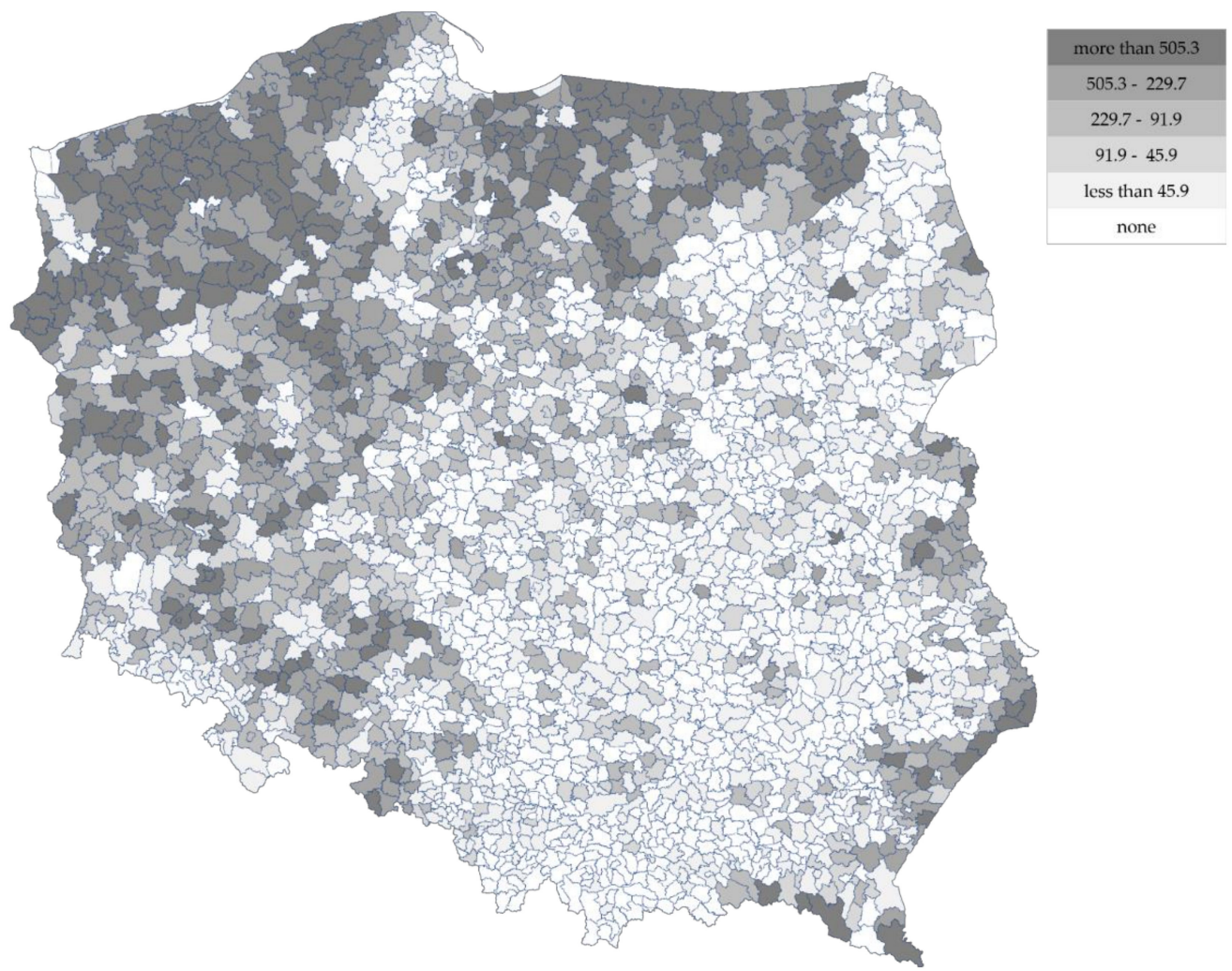

Figure 4. Number of flats sold from state-owned farm resources per 10,000 total population $\left(W_{1}\right)$ in communes. Source: The authors' calculations based on data of: KOWR and GUS.

Before discussing the results at the commune level, it should be clarified that stateowned farms operated in Poland in all types of communes (urban, urban-rural, and rural), but mostly in rural communes.

Figure 4 shows that most communes with a high value of this indicator are located in the north-western and north-eastern areas of Poland, although the highest value of $W_{1}=2251.1$ was observed in the village of Dołhobyczów (poviat of Hrubieszów, Lubelskie voivodeship). In 919 communes, there was no sale of flats from state-owned farms. The structure of communes by commune type, together with the information on how many communes of given type flats from state-owned farms were sold and how many did not have such sales, are presented in Table 3.

Table 3. Structure of communes by commune type, taking into account the number of flats sold from the state-owned farm resources.

\begin{tabular}{cccc}
\hline Type of Commune $^{\mathbf{1}}$ & $\begin{array}{c}\text { Number of } \\
\text { Communes }\end{array}$ & $\begin{array}{c}\text { Communes with the } \\
\text { Sale of Flats }\end{array}$ & $\begin{array}{c}\text { Communes without } \\
\text { Sale of Flats }\end{array}$ \\
\hline urban & 236 & 85 & 151 \\
urban-rural & 638 & 477 & 161 \\
rural & 1537 & 930 & 607 \\
\hline Overall & 2411 & 1492 & 919 \\
\hline
\end{tabular}

${ }^{1}$ an urban commune-commune with the status of a city; a rural commune-there are only villages on its territory; an urban-rural commune-one unit has the status of the city, and the rest of the commune is a rural area [42]. Source: The authors' calculations based on data of: KOWR and GUS.

Based on the data in Table 3, it can be seen that the greatest number of flats in absolute terms were sold in rural communes and the least in urban communes. The relationship between the type of commune and the fact of selling flats or not selling them is confirmed by the correlation measure for qualitative traits (Cramer's $\mathrm{V}$ coefficient), which was obtained at the level of 0.217 (Pearson's $\chi^{2}=113.056, p=0.0000$ ). 
Similarly, as in the case of poviats, a regression tree was used for communes, in which the dependent variable was the indicator $W_{1}$, and the independent variables were indicators $W_{2}-W_{8}, W_{10}$, and $W_{13}$, while the indicator $W_{13}$ (commune type) is a qualitative variable with the following variants: municipal commune, urban-rural commune, and rural commune. As a result of the applied C\&RT procedure, a sequence of 17 trees was obtained for commune $(n=2411)$, of which tree no. 12 was selected (Figure 5) with five shared nodes and six terminal nodes.

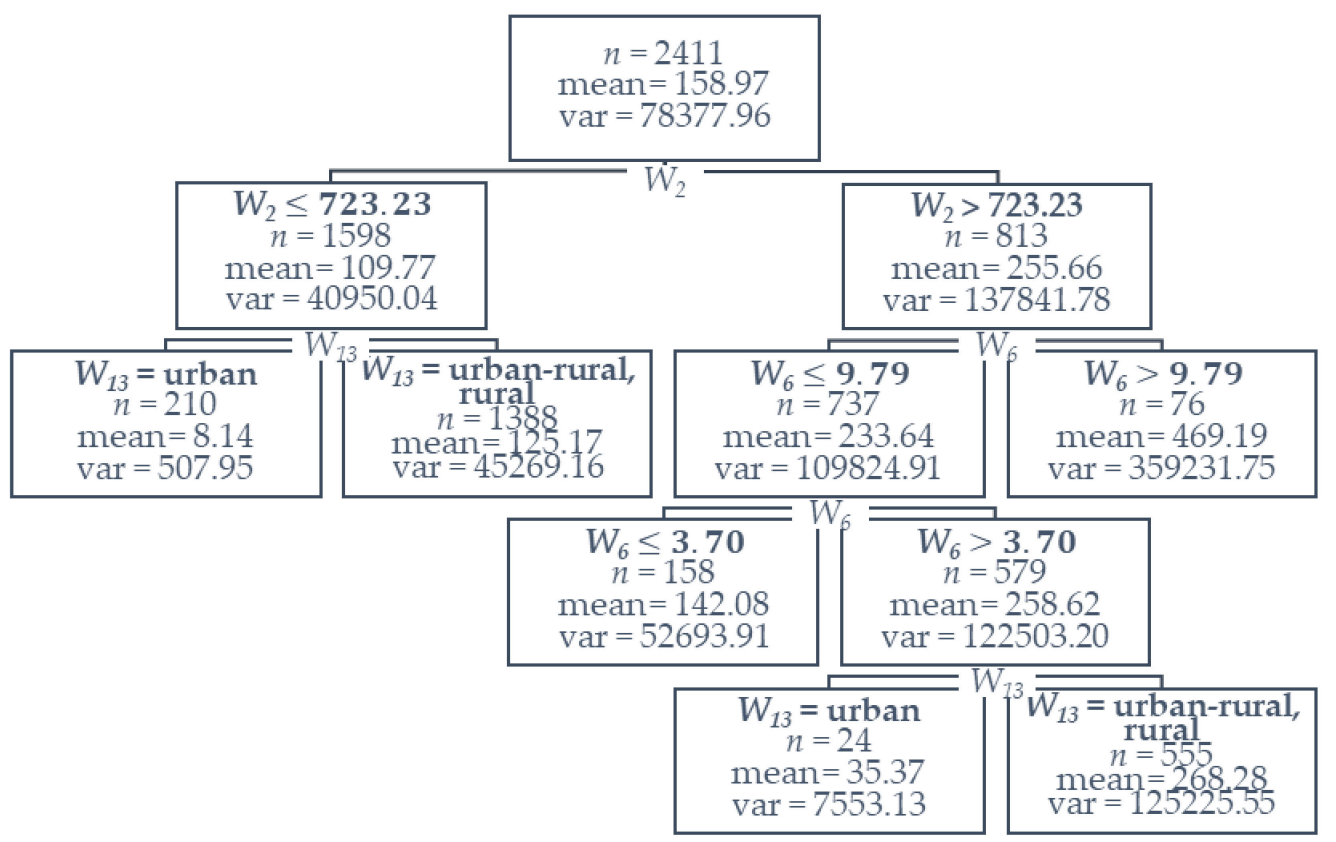

Figure 5. Regression tree for the indicator $W_{1}$ at the commune level. Source: The authors' calculations in Statistica 13, based on data of: KOWR and GUS.

For communes, as for poviats, only three indicators $W_{2}$ (the number of community social assistance beneficiaries per 10,000 population), $W_{6}$ (the share of the unemployed in the working-age population), and $W_{13}$ (commune type) were used to build a selected tree, based on in which six groups of communes were separated, differing significantly in the values of the indicator $W_{1}$. The selected groups of communes are characterized as follows:

- group I $(n=210)$ - if the number of beneficiaries per 10,000 population does not exceed 723.5 and if it is an urban commune, the average value of the $W_{1}$ indicator is 8.14 , and the variance is 507.95;

- group II $(n=1388)$ - if the number of beneficiaries per 10,000 of the population does not exceed 723.5 and if it is an urban-rural or rural commune, the average value of the indicator $W_{1}$ is 125.17 , and the variance is $45,269.16$;

- group III $(n=76)$-if the number of beneficiaries per 10,000 population is above 723.5 and if the share of the unemployed in the working-age population does not exceed $9.79 \%$, the average value of the $W_{1}$ indicator is 469.19 , and the variance is $359,231.18$;

- group IV $(n=158)$ - if the number of beneficiaries per 10,000 of the population is above 723.5 and if the share of the unemployed in the working-age population does not exceed $3.7 \%$, the average value of the $W_{1}$ indicator is 142.08 , and the variance is $52,693.91$;

- $\quad$ group V $(n=24)$-if the number of beneficiaries per 10,000 population is above 723.5 and if the share of the unemployed in the working-age population is in the range $\left(3.7 \% ; 9.79 \%>\right.$ and it is an urban commune, the average value of the indicator $W_{1}$ is 35.37 , and the variance is 7553.13 ;

- group VI $(n=54)$-if the number of beneficiaries per 10,000 population is above 723.5 and if the share of the unemployed in the working-age population is in the range 
(3.7\%; $9.79 \%>$ and it is an urban-rural or rural commune, the average value of the indicator $W_{1}$ is 268.28 , and variance $125,225.55$.

Considering the above characteristics from the point of view of the $W_{1}$ indicator, we can observe the following regularities:

- the lowest values of the $W_{1}$ indicator are in urban communes where the number of people using community social assistance is lower than in urban-rural and rural communes, and the share of the unemployed in the working-age population is relatively low;

- higher values of the $W_{1}$ indicator can be noticed in urban-rural and rural communes, and in these communes, the number of beneficiaries of community social assistance is increasing immediately, and the share of the unemployed in the working-age population is higher;

- $\quad$ and regardless of the commune type, the highest level of the $W_{1}$ indicator is in those communes where there are many beneficiaries of community social assistance, and the share of the unemployed in the working-age population is high (over 9\%).

The above regularities confirm the conclusions obtained for poviats, while at this level of aggregation, it is clearly visible that in urban communes, the standard of living is higher than in rural areas. Moreover, it can be noticed that regardless of the type of commune, if there used to be state-owned farms in its territory, the population still has financial problems, and it is difficult for them to find their place on the labor market.

Similarly to poviats, Table 4 presents the values of selected parameters characterizing the distributions of individual indicators' values in the groups of communes separated based on the regression tree.

Table 4. Parameters of the distribution of the values of indicators in the groups of communes ordered in ascending order according to the average values of the indicator $W_{1}$.

\begin{tabular}{|c|c|c|c|c|c|c|c|c|}
\hline Groups & Parameters & $W_{1}$ & $W_{2}$ & $W_{6}$ & $W_{7}$ & $W_{8}$ & $W_{10}$ & $W_{13}$ \\
\hline \multirow{3}{*}{$\begin{array}{c}\mathrm{I} \\
n=210\end{array}$} & mean & 8.14 & 409.29 & 4.10 & 5165.82 & 2703.99 & 106.12 & \multirow{3}{*}{$100 \%$ urban } \\
\hline & Vs [\%] & 276.80 & 33.67 & 46.23 & 18.55 & 29.64 & 12.85 & \\
\hline & asymmetry & 5.15 & 0.27 & 0.82 & 1.30 & 1.72 & 1.24 & \\
\hline \multirow{3}{*}{$\begin{array}{c}\mathrm{V} \\
n=24\end{array}$} & mean & 35.37 & 930.50 & 6.79 & 5804.30 & 2902.87 & 105.00 & \multirow{3}{*}{$100 \%$ urban } \\
\hline & Vs [\%] & 245.70 & 23.80 & 19.01 & 62.54 & 114.84 & 15.42 & \\
\hline & asymmetry & 3.91 & 1.21 & -0.74 & 4.75 & 4.82 & 0.13 & \\
\hline \multirow{3}{*}{$\begin{array}{c}\text { II } \\
n=1388\end{array}$} & mean & 125.17 & 443.89 & 3.86 & 5281.26 & 2140.02 & 88.99 & \multirow{3}{*}{$\begin{array}{c}68 \% \text { urban-rural } \\
32 \% \text { rural }\end{array}$} \\
\hline & Vs [\%] & 169.99 & 34.94 & 53.96 & 26.75 & 67.06 & 15.34 & \\
\hline & asymmetry & 2.57 & -0.11 & 1.32 & 17.81 & 15.65 & 8.22 & \\
\hline \multirow{3}{*}{$\begin{array}{c}\mathrm{IV} \\
n=158\end{array}$} & mean & 142.08 & 958.35 & 2.85 & 5585.62 & 1784.29 & 89.08 & \multirow{3}{*}{$\begin{array}{c}1 \% \text { urban } \\
76 \% \text { urban-rural } \\
23 \% \text { rural }\end{array}$} \\
\hline & Vs [\%] & 161.57 & 25.26 & 23.34 & 14.46 & 43.41 & 9.92 & \\
\hline & asymmetry & 2.18 & 1.73 & -0.82 & 1.80 & 3.60 & -0.60 & \\
\hline \multirow{3}{*}{$\begin{array}{c}\mathrm{VI} \\
n=555\end{array}$} & mean & 268.28 & 1048.44 & 6.14 & 5302.99 & 1688.81 & 85.28 & \multirow{3}{*}{$\begin{array}{c}75 \% \text { urban-rural } \\
25 \% \text { rural }\end{array}$} \\
\hline & Vs [\%] & 131.91 & 28.33 & 25.68 & 13.19 & 41.26 & 10.96 & \\
\hline & asymmetry & 1.70 & 1.56 & 0.34 & 2.55 & 3.09 & -0.62 & \\
\hline \multirow{3}{*}{$\begin{array}{c}\text { III } \\
n=76\end{array}$} & mean & 469.19 & 1235.92 & 11.62 & 5167.73 & 1613.25 & 82.62 & \multirow{3}{*}{$\begin{array}{c}1 \% \text { urban } \\
75 \% \text { urban-rural } \\
24 \% \text { rural }\end{array}$} \\
\hline & Vs [\%] & 127.74 & 31.65 & 15.57 & 13.28 & 47.38 & 16.45 & \\
\hline & asymmetry & 1.20 & 0.99 & 1.95 & 2.02 & 3.20 & -0.21 & \\
\hline
\end{tabular}

Source: The authors' calculations based on data of: KOWR and GUS.

As for poviats, the average values of the indicators indicate that along with the increase in the average values of the indicator $W_{1}$ :

- the number of people benefiting from community social assistance increases (the exception is group II, where there are clearly fewer beneficiaries of social assistance than in the next group); 
- total incomes and own incomes per capita decrease (the exception is group I, where incomes are lower than in the next group);

- $\quad$ and the gross enrollment index is decreasing (the exception is group IV, where this index is higher than in the previous group).

In the case of the indicator $W_{6}$, such an unambiguous regularity cannot be observed, although in most groups, the higher the values of the $W_{1}$ indicator, the higher the unemployment.

The most significant differentiation in all groups of communes can be observed for the indicator $W_{1}\left(V_{s}>100 \%\right)$, while the smallest for the indicator $W_{10}\left(V_{s}<17 \%\right)$. Groups of communes are quite diversified due to the index $W_{8}$ ( $V_{s}$ for most groups exceeds $40 \%$ ). In the case of the $W_{2}$ indicator, the variation measure ranges from $23 \%$ to $35 \%$, for the $W_{6}$ indicator it ranges from $19 \%$ to $54 \%$, and for the $W_{7}$ indicator it ranges from $13 \%$ to $63 \%$.

For most groups of communes, the distribution of indicators is characterized by a solid right-hand asymmetry (the asymmetry measure is above 1), which means that in these groups, the commune distribution of indicators prevails below the average. Left-hand asymmetry occurs only in a few cases and concerns mainly the distribution of the $W_{10}$ index, which means that in these groups prevail communes for which the enrollment index is above average.

\section{Discussion}

Poland's accession to the European Union created the conditions for overcoming the rural income collapse that accompanied the political transformation of the 1990s and the first half of the past decade. Of particular importance in this respect are the transfers to agriculture and rural areas under the Common Agricultural Policy, transfers, and inflow of capital for development and creation of jobs outside agriculture, as well as making the labor market available in Western European countries for Polish workers, including those from the rural areas. The income of rural households since the preaccession period has increased more than that of urban households. In the years 2002-2016, the disposable income of rural households in Poland more than doubled (nominal increase by 130.3\%), and the average household income in the city increased slightly less, by $117.5 \%$ [43]. However, this does not mean that the income disparity of rural residents, and especially of the areas where state-owned farms operated, has completely disappeared. As research shows in this area, it is still significant. In the initial period of accession to the European Union (until 2007), there was a constant downward trend in the disparity of farmers' household income in relation to the income of other socioeconomic groups. Later, this ratio was constantly fluctuating; however, farmers' households are invariably characterized by the lowest average monthly disposable income per person. In 2016, farmers' household incomes accounted for $78.1 \%$ of the average for Poland, and rural poverty rates are still high, despite a relatively significant downward trend in recent years. Nevertheless, there is a decrease in the percentage of inhabitants of rural areas who evaluate their financial situation as worse, and a growing percentage of inhabitants who are satisfied [43].

The research results presented in this article confirm that the socioeconomic situation of the population in rural areas differs significantly from the situation in urban areas. This is clearly visible in the structure of the constructed regression trees, regardless of the degree of aggregation of the output data-in each analyzed tree of the values used in their construction, the indicators emphasized these disproportions. These inequalities (disproportions) have been the subject of many studies, reports, and scientific works [44-47]. Numerous studies show that the level of income of the rural population is usually lower than that of urban residents (see, e.g., [48-50]), hence the higher level of social transfers in rural communes or poviats with a large share of the rural population. Such a pattern is visible not only in Poland but also in other European countries [51], or the world [52]. The negative effect of social transfers is the poverty trap [53,54]. It makes social assistance beneficiaries try to keep their income below the set limit, ensuring access to benefits. This has a direct impact on the reduction of their mobility and the lack of measures taken to improve their financial situation. 
Intriguing research results concerning the socioeconomic situation in rural areas in Poland were presented by Bartkowiak-Bakun [55]. Although these studies did not show a simple relationship between rural development and the share of former state-owned farms in communes, they confirmed a considerable differentiation of this development in rural areas while indicating that rural areas with a good level of development are concentrated near large cities (e.g., Wrocław and Szczecin). Therefore, it can be concluded that the location close to large urban agglomerations triggered development processes and helped to break the barriers resulting from the liquidation of state-owned farms. Ogolo [56] came to similar conclusions by studying the socioeconomic role of urban centers in the development of rural areas in Nigeria. This is also confirmed by the results of the research conducted by the authors of this study, which show that in rural and urban-rural communes distant from large urban centers, the standard of living of the population is lower (see Figures 4 and 5).

Often the problem of the post-state farm population is related to the problem of poverty and its intergenerational reproduction. In order to explain this issue, the slogan of "learned helplessness" is repeated, although not all of it [57]. The former state-owned areas are a recurring subject of media discourse, a specific, very negative image of the "former state-owned estate" has developed in the common consciousness. During the period of state-owned farms, the population was often used to extensive social welfare and for that reason, with the advent of the new system, they cannot find their way in it. Therefore, in these areas there is poverty, perpetuated by the benefit system and the lack of activating forms of social policy. The liquidation of state-owned farms took place without any special protective measures. There was also no major special program aimed at employees of state-owned farms. They were offered only funds available under the general framework of labor market policies, and people with longer work experience and of the appropriate age could take advantage of deactivation benefits, mainly early retirement. Special programs were few and they were launched on a small scale. In Poland, the typical, and thus the most common type of poviat in which state-owned farms operated, lies among other economically similar poviats in the north-western belt, settled after the war. They have some common features, including [58]: a dispersed settlement structure without clear economic specialization, poor public transport connectivity, low level of educational and professional activity, and a very weak inflow of external capital.

The problems of the rural population presented above, particularly in areas where state-owned farms once dominated, and the research results lead to the search for solutions to compensate for disparities in the standard of living. Given the often difficult situation of rural areas and agriculture, more and more experts and institutions recognize the implementation of multifunctionality principles as a way to revive rural areas and reverse negative development trends [59-65]. The multifunctional development of rural areas consists of abandoning agriculture as the sole or dominant function and much greater diversification of the economy. This means the development of agricultural and food functions and all forms of service and industrial activities, especially those that do not threaten the natural environment. The growth potential of rural communes is a critical determinant of multifunctional development.

\section{Conclusions}

The study includes the results of research on the identification of the spatial diversity of former state-owned farm areas in Poland at individual levels of data aggregation (voivodeship, poviat, and commune) and the comparison of the socioeconomic situation of the population living in these areas with the situation of the population from areas where there were no state-owned farms. The basis for the identification of former state-owned farm areas was the indicator $W_{1}$ (the number of flats sold from the PPGR resources per 10,000 of the total population), while to characterize the socioeconomic situation of the population, from 8 (for communes) to 11 (for voivodeships) indicators were proposed.

The spatial differentiation of the value of the index $W_{1}$ at different levels of data aggregation is presented graphically. The analysis of the charts made it possible to clearly 
identify those areas in Poland where the intensity of the studied phenomenon was significant. It turned out that the largest number of former state-owned farms are located primarily in the north-west and north-east of Poland.

The use of correlation analysis for voivodeships and regression trees at the level of poviats and communes allowed for the detection of significant regularities concerning the standard of living of the population in rural and urban areas. They confirmed the hypothesis that households' economic situation in former state-owned farms is worse than in areas where there were no state farms. Among the beneficiaries of social assistance, most people live in rural areas and those with a high unemployment rate, while the problem of unemployment concerns those areas where the rural population with lower education predominates. Moreover, in the area of former state-owned farms, the total disposable income per person is lower, and the funds from the government program "Rodzina 500+" constitute a significant contribution to household budgets. It has also been shown that the increase in the number of former state-owned farm flats sold causes an increase in the number of beneficiaries of community social assistance, the scope of using community social assistance, and the level of the unemployment rate. This is also confirmed by the results of the CSO research, stating that in 2019 the most common reasons for using social assistance by poor beneficiaries (apart from the low financial status) were problems related to poor health or disability (they occurred in over $58 \%$ of households) and unemployment (54.5\% of farms).

It is worth paying attention to one more regularity related to the sale of flats from the state-owned farms' resources. It turned out that in poviats with a higher percentage of the rural population, the average number of flats sold was lower than in poviats with a lower percentage. On the one hand, this may suggest the low income of the people living there, making it impossible to purchase real estate, and on the other hand, the lack of willingness or the possibility of purchasing it. The large size of this group of poviats (91, i.e., $23.9 \%$ of the population) indicates at the same time a wide range of problems identified in the study. Additionally, the long period that has elapsed since the liquidation of the State Agricultural Enterprises and the lack of population efforts to purchase housing suggest that these people have fallen into the poverty trap.

Summarizing the above conclusions, it can be stated that in the areas where stateowned farms used to operate, the population still has financial problems, and it is difficult for them to find their place in the labor market.

In Poland and many European countries, the population of rural areas still lags behind urban areas in terms of conditions and quality of life. Therefore, strengthening the development policy for these areas is now a priority of the European Union, which conducts an active policy in this area [66]. Promoting employment and combating poverty in rural areas, and improving the quality of life are essential direct and indirect objectives of the EU's rural development policy. These goals are reflected in the EU's Europe 2020 strategy, which sets out a vision for the European social market economy in the 21st century and the objectives of the 2010 European Year for Combating Poverty and Social Exclusion. The latter EU-wide campaign is a unique opportunity to raise awareness of poverty and social exclusion in rural areas [67]. Since 25 September 2015, The United Nations General Assembly has adopted 17 Sustainable Development Goals to fight poverty, protect our planet and ensure prosperity for all under a new agenda for sustainable development called the 2030 Agenda [68]. For each of the 17 targets, specific targets (169 in total) have been set to be achieved by 2030. The EU was the leading force behind the 2030 Agenda and its Sustainable Development Goals. Of the 169 goals set to achieve the SDGs, 132 (78\%) are at least partly related to the rural sector, and every fifth relates exclusively or mainly to rural areas $[69,70]$.

In the future, research into the situation in former state-owned areas should be continued so that a complete diagnosis of these areas can be made in the context of the changing demographic, market, and institutional situation (e.g., the effects of the COVID-19 pandemic). The obtained results should support creating a set of instruments for compre- 
hensive socioeconomic support for areas threatened by permanent marginalization and degradation. These instruments can update national and regional development policies regarding medium-term strategy and sectoral strategies (mainly rural development, labor market, and social policy). It is necessary to maintain social cohesion and prevent the further marginalization of the inhabitants of former state-owned areas.

The authors are aware that the research results presented in the article are general, concerning the entire territory of Poland - that is, both rural communes, as well as urbanrural and urban communes-but they still allowed to identify interesting regularities in the situation of rural areas, with particular emphasis on former state-owned farms. In order to supplement and extend them, future research conducted by the authors will focus on comparing the socioeconomic situation of the population in two communities: in the areas formerly state-owned and other.

Author Contributions: Conceptualization, I.B., K.W. and M.O.; methodology, I.B. and K.W.; software, M.O.; validation, I.B., K.W. and M.O.; formal analysis, I.B., K.W. and M.O.; investigation, I.B., K.W. and M.O.; resources, I.B., K.W. and M.O.; data curation, M.O.; writing-original draft preparation, I.B., K.W. and M.O.; writing-review and editing, I.B., K.W. and M.O.; visualization, K.W. and M.O.; supervision, I.B.; project administration, I.B; funding acquisition, I.B. All authors have read and agreed to the published version of the manuscript.

Funding: This research received no external funding.

Institutional Review Board Statement: Not applicable.

Informed Consent Statement: Not applicable.

Data Availability Statement: Not applicable.

Conflicts of Interest: The authors declare no conflict of interest.

\section{References}

1. Grykień, S. Transformacja Rolnictwa w Krajach Europy Środkowo-Wschodniej. Przegląd Geogr. 2005, 77, $213-233$.

2. Halamska, M. Transformacja Wsi 1989-2009: Zmienny Rytm Modernizacji. Studia Reg. Lokalne 2011, 44, 5-25.

3. Perry, C.S. Economic Activity and Social Indicators: A Rural-Urban Discontinuum? Am. J. Econ. Sociol. 1984, 43, 61-74. [CrossRef]

4. Khan, M.H. Rural Poverty in Developing Countries: Implications for Public Policy; International Monetary Fund: Washington, DC, USA, 2001; Volume 26.

5. Blumenthal, S.J.; Kagen, J. The Effects of Socioeconomic Status on Health in Rural and Urban America. JAMA 2002, 287. [CrossRef]

6. Tsymbalista, N. Socio-Economic Conditions Of Life Of The Rural Population As An Incentive For The Rural Economy Development: The Case Of Chernivtsi Region In Ukraine. Agric. Econ. Rural Dev. 2016, 13, 25-34.

7. Vorobyov, S.; Bugai, Y. Factors of Socio-Economic Development of Rural Areas. IOP Conf. Ser. Earth Environ. Sci. 2019, 395. [CrossRef]

8. Pavel, A.; Moldovan, O. Determining Local Economic Development in the Rural Areas of Romania. Exploring the Role of Exogenous Factors. Sustainability 2019, 11, 282. [CrossRef]

9. Stolarska, A. Non-Agricultural Entrepreneurship of Rural Women as a Factor Eliminating Socio-Economic Inequalities and Influencing Rural Area Development. Ann. Pol. Assoc. Agric. Agribus. Econ. 2019, 21, 486-494. [CrossRef]

10. Salgotra, A.K. Socio-Economic Status of Rural Families: With Special Reference to BPL Households of Pauri District of Uttarakhand. IOSR J. Humanit. Soc. Sci. 2017, 22, 16-20. [CrossRef]

11. Shedenova, N.; Beimisheva, A. Social and Economic Status of Urban and Rural Households in Kazakhstan. Procedia Soc. Behav. Sci. 2013, 82, 585-591. [CrossRef]

12. Kulkarni, P.; Ramesh Masthi, N. Gangaboraiah An Exploratory Study on Socio Economic Status Scales in a Rural and Urban Setting. J. Fam. Med. Prim. Care 2013, 2, 69-73. [CrossRef]

13. European Commission. Socio-Economic Challenges Facing Agriculture and Rural Areas; European Commission: Brussel, Belgium, 2017.

14. Chand, R.; Srivastava, S.K.; Singh, J. Changing Structure of Rural Economy of IndiaImplications for Employment and Growth; Discussion Paper; NITI Aayog: New Delhi, India, 2017.

15. Kalamkar, S.S. Urbanisation and Agricultural Growth in India. Ind. J. Agri. Econ. 2009, 64, 442-461.

16. International Labour Organization Rural Economy. Available online: https://www.ilo.org/global/topics/dw4sd/themes/ruraleconomy/lang--en/index.htm (accessed on 2 March 2021).

17. International Labour Organization. World Employment Social Outlook 2016. Transforming Jobs to End Poverty; International Labour Organization: Geneva, Switzerland, 2016.

18. European Commission. Poverty and Social Exclusion in Rural Areas, Executive Summary; European Commission: Brussel, Belgium, 2008. 
19. Parker, K.; Horowitz, J.M.; Brown, A.; Fry, R.; Cohn, D.; Ruth, I. 4. Views of Problems Facing Urban, Suburban and Rural Communities. Available online: https://www.pewresearch.org/social-trends/2018/05/22/views-of-problems-facing-urbansuburban-and-rural-communities/ (accessed on 18 March 2021).

20. Barrios, E.B. Infrastructure and Rural Development: Household Perceptions on Rural Development. Prog. Plan. 2008, 70, 1-44. [CrossRef]

21. Keats, S.; Wiggins, S. Population Change in the Rural Developing World: Making the Transition; Overseas Development Institute: London, UK, 2016.

22. Chapman, R.; Slaymaker, T. ICTs and Rural Development: Review of the Literature, Current Interventionsand Opportunities for Action; Overseas Development Institute: London, UK, 2002.

23. Cook, J.R.; Huizenga, C.; Petts, R.; Sampson, L.R.; Visser, C.; Yiu, A. Rural Transport Research in Support of Sustainable Development Goals. Transp. Commun. Sustain. Dev. Goals 2017, 89.

24. University Of Minnesota. Social Problems. Continuity and Change; University Of Minnesota Libraries Publishing: Minneapolis, MN, USA, 2015.

25. Lavalley, M. Out of the Loop. Rural Schools Are Largely Left out of Research and Policy Discussions, Exacerbating Poverty, Inequity, and Isolation; Center for Public Education: Alexandria, VA, USA, 2018.

26. Janeska, V.; Bojnec, Š. Rural Labour Market Developments in the Former Yugoslav Republic of Macedonia; Factor Markets Working Papers 101; Centre for European Policy Studies: Brussels, Belgium, 2011.

27. Tocco, B.; Davidova, S.; Bailey, A. Key Issues in Agricultural Labour Markets A Review of Major Studies and Project Reports on Agriculture and Rural Labour Markets; Working Paper; Centre for European Policy Studies: Brussels, Belgium, 2012.

28. Roy, N.S.; Mukhopadhyay, I. Emerging Challenges of Rural Labour Market: Insights from Indian Villages. Arthaniti J. Econ. Theory Pract. 2019, 18, 86-103. [CrossRef]

29. Bertolini, P. Overview of Income and Non-Income Rural Poverty in Developed Countries; United Nations Economic Commission for Africa: Addis Ababa, Ethiopia, 2019.

30. Van Dijk, T. Land Consolidation as Central Europe's Panacea Reassessed. In Symposium in Volvic (Clermont-Ferrand), Proceedings of Symposium on Modern Land Consolidation, Volvic, France, 10-11 September 2004; International Federation of Surveyors: Frederiksberg, Denmark, 2004.

31. Sroka, W. Historyczne Uwarunkowania Dominacji Drobnych Gospodarstw Rolnych w Rolnictwie Europy Środkowo-Wschodniej. Probl. Drob. Gospod. Rol. 2015, 4, 61-73. [CrossRef]

32. Breiman, L.; Friedman, J.H.; Olshen, R.A.; Stone, C.J. Classification and Regression Trees; Chapman \& Hall/CRC: New York, NY, USA, 1984; ISBN 0-412-04841-8.

33. Gatnar, E. Podejscie Wielomodelowe w Zagadnieniach Dyskryminacji i Regresji; Wydawnictwo Naukowe PWN: Warszawa, Poland, 2008; ISBN 9788301153663.

34. Izenman, A.J. Modern Multivariate Statistical Techniques; Springer: New York, NY, USA, 2008; ISBN 978-0-387-78188-4.

35. Loh, W. Classification and Regression Trees. Wires Data Min. Knowl. Discov. 2011, 1, 14-23. [CrossRef]

36. Gatnar, E.; Walesiak, M. Metody Statystycznej Analizy Wielowymiarowej w Badanich Marketingowych; Akademia Ekonomiczna we Wrocławiu: Wrocław, Poland, 2004; ISBN 83-7011-703-1.

37. Agresti, A. Categorical Data Analysis, 3rd ed.; John Wiley \& Sons: Hoboken, NJ, USA, 2013; ISBN 978-0-470-46363-5.

38. Harrell, F.E. Regression Modeling Strategies, 2nd ed.; Springer International Publishing: Cham, Switzerland, 2015; ISBN 978-3-319-19424-0.

39. Statsoft Elektroniczny Podręcznik Statystyki PL. Available online: https://www.statsoft.pl/textbook/stathome.html (accessed on 18 March 2021).

40. Gorzelak, E. Polskie Rolnictwo w XX Wieku. Produkcja i Ludność.; Prace i Materiały; Szkoła Główna Handlowa w Warszawie: Warszawa, Poland, 2010.

41. Walesiak, M.; Gatnar, E. Statystyczna Analiza Danych z Wykorzystaniem Programu R; Wydawnictwo Naukowe PWN: Warszawa, Poland, 2009; pp. 1-468.

42. GUS Ogólna Charakterystyka Systemów Rejestru. Rejestr TERYT. Available online: https://eteryt.stat.gov.pl/eTeryt/rejestr_ teryt/ogolna_charakterystyka_systemow_rejestru/ogolna_charakterystyka_systemow_rejestru.aspx?contrast=default (accessed on 23 April 2021).

43. Ministerstwo Rolnictwa i Rozwoju Wsi. Diagnoza Sytuacji Społeczno-Gospodarczej Rolnictwa, Obszarów Wiejskich i Rybactwa w Polsce; Ministerstwo Rolnictwa i Rozwoju Wsi: Warszawa, Poland, 2019.

44. Eastwood, R.; Lipton, M. Rural-Urban Dimensions OfInequality Change; Working Papers; UNU/WIDER Publications: Helsinki, Finland, 2000.

45. Chen, D.; Norgaard, S. Challenging Inequality at the Edge of Change: Spatial Inequality, Equitable Development, and Urban-Rural Linkages; Working Paper; Rimisp: Santiago, Chile, 2016.

46. Florida, R. The Growing Inequality between America's Superstar Cities, and the Rest. Available online: https://www.bloomberg. com/news/articles/2018-11-19/urban-rural-spatial-inequality-is-getting-worse (accessed on 2 March 2021).

47. Camarero, L.; Oliva, J. Thinking in Rural Gap: Mobility and Social Inequalities. Palgrave Commun. 2019, 5. [CrossRef]

48. Calì, M. Urbanisation, Inequality and Economic Growth: Evidence from Indian States and Towns; Background Note for the World Development Report 2009; Overseas Development Institute: London, UK, 2008. 
49. Shi, L.; Chuliang, L. Re-Estimating the Income Gap between Urban and Rural Households in China. Procedia Soc. Behav. Sci. 2010, 2, 7151-7163. [CrossRef]

50. Imai, K.S.; Malaeb, B. Asia's Rural-Urban Disparity in the Context of Growing Inequality; IFAD Research Series 27; International Fund for Agricultural Development: Rome, Italy, 2018.

51. Miežienè, R.; Krutulienè, S. The Impact of Social Transfers on Poverty Reduction in EU Countries. Balt. J. Eur. Stud. 2019, 9, 158-175. [CrossRef]

52. Barrientos, A. Social Transfers and Growth: A Review. Ssrn Electron. J. 2008, 112. [CrossRef]

53. Matsuyama, K. Poverty Traps. In The New Palgrave Dictionary of Economics; Durlauf, S., Blume, L.E., Eds.; Palgrave Macmillan UK: London, UK, 2008; ISBN 978-0-333-78676-5.

54. Kraay, A.; McKenzie, D. Do Poverty Traps Exist? Assessing the Evidence. J. Econ. Perspect. 2014, 28, 127-148. [CrossRef]

55. Bartkowiak-Bakun, N. The Diversity of Socioeconomic Development of Rural Areas in Poland in The Western Borderland and the Problem of Post-State Farm Localities. Oeconomia Copernic. 2017, 8, 417-432. [CrossRef]

56. Ogolo, J.I. The Role of Socio-Economic Issues of Urban Centres in Rural Development. In WIT Transactions on Ecology and the Environment; WIT Press: Bilbao, Spain, 2011; pp. 265-275.

57. Nowak, T.; Pokropek, A.; Rogaczewska, M.; Urbanik, A. Rynki Pracy Na Obszarach Popegeerowskich. Załacznik 2a: Monografia Powiatu Bytowskiego; Ministerstwo Rodziny i Polityki Społecznej: Warszawa, Poland, 2008.

58. Liwiński, J.; Sztanderska, U.; Giza-Poleszczuk, A. Rynki Pracy Na Obszarach Popegeerowskich. Raport z Badań; Ministerstwo Pracy i Polityki Społecznej: Warszawa, Poland, 2008.

59. van der Ploeg, J.D.; Renting, H.; Brunori, G.; Knickel, K.; Mannion, J.; Marsden, T.; de Roest, K.; Sevilla-Guzman, E.; Ventura, F. Rural Development: From Practices and Policies towards Theory. Sociol. Rural. 2000, 40, 391-408. [CrossRef]

60. Cairol, D.; Coudel, E.; Knickel, K.; Caron, P.; Kröger, M. Multifunctionality of Agriculture and Rural Areas as Reflected in Policies: The Importance and Relevance of the Territorial View. J. Environ. Policy Plan. 2009, 11, 269-289. [CrossRef]

61. Wilson, G. Multifunctional "quality" and Rural Community Resilience. Trans. Inst. Br. Geogr. New Ser. 2010, 35, 364-381. [CrossRef]

62. Bórawski, P. (Ed.) Multifunctional Development of Rural Areas. International Experience; High Economic Social School Publishing House: Ostrołeka, Poland, 2012; ISBN 978-83-929620-7-6.

63. Kocur-Bera, K. Multifunctional Rural Development-A Comparative Analysis of Municipalities Adjacent to the City of Olsztyn. In Proceedings of the International Scientific Conference "RURAL DEVELOPMENT 2017", Akademija, Lithuani, 23-24 November 2017; Aleksandras Stulginskis University: Akademija, Lithuania, 2018.

64. Ma, W.; Jiang, G.; Li, W.; Zhou, T.; Zhang, R. Multifunctionality Assessment of the Land Use System in Rural Residential Areas: Confronting Land Use Supply with Rural Sustainability Demand. J. Environ. Manag. 2019, 231, 1092-1097. [CrossRef] [PubMed]

65. Ristić, L.; Despotović, D.; Dimitrijević, M. Multifunctionality of Agriculture as a Significant Factor for Sustainable Rural Development of the Republic of Serbia. Econ. Themes 2020, 58, 17-32. [CrossRef]

66. Tangermann, S.; von Cramon-Taubadel, S. Agricultural Policy in the European Union. An Overview; Diskussionsbeitrag No. 1302; Department for Agricultural Economics and Rural Development, University of Goettingen: Göttingen, Germany, 2013.

67. European Commission Przegląd Obszarów Wiejskich UE. Magazyn Europejskiej Sieci na rzecz Rozwoju Obszarów Wiejskich; European Commission: Brussels, Belgium, 2010.

68. Bąk, I.; Cheba, K. Zielona Gospodarka Jako Narzędzie Zrównoważonego Rozwoju; CeDeWu: Warszawa, Poland, 2020; ISBN 978-83-8102-346-7.

69. Saravia-Matus, S.L.; Aguirre Hörmann, P.; Berdegué, J.A. Environmental Efficiency in the Agricultural Sector of Latin America and the Caribbean 1990-2015: Are Greenhouse Gas Emissions Reducing While Agricultural Production Is Increasing? Ecol. Indic. 2019, 102, 338-348. [CrossRef]

70. Trivelli, C.; Berdegué, J.A. Rural Transformation Rural Transformation Looking towards the Future of Latin America and the Caribbean; FAO: Santiago, Chile, 2019. 